\title{
Studies on Standardization and Physic-chemical Characteristics of Elephant Foot Yam (Amorphophallus paeoniifolius) Papad
}

\section{Venkatraman Bansode ${ }^{1 *}$, Vijay Bahadur Singh Chauhan ${ }^{1}$, Kalidas Pati ${ }^{1}$, Kiran Bhuyar ${ }^{2}$, Sudhansu Shekhar Mahanand $^{3}$ and M. Nedunchezhiyan ${ }^{1}$}

\author{
${ }^{1}$ ICAR-Central Tuber Crops Research Institute, Regional Centre, Dumduma H.B, \\ Bhuaneswar-751019 (Odisha), India \\ ${ }^{2}$ Priyadarshani Institute of Engineering and Technology, RTMNU, \\ Nagpur-440009 (M.S), India \\ ${ }^{3}$ College of Fisheries, CAU, Lembucherra-799210 (Tripura), India
}

*Corresponding author

\section{A B S T R A C T}

\section{Keywords \\ Elephant foot yam, Papad preparation, Nutritional composition, Physical characteristics, Oraganoleptic evaluation \\ Article Info \\ Accepted: \\ 10 April 2019 \\ Available Online: \\ 10 May 2019}

\begin{abstract}
The present study was undertaken to develop protocol for preparation of elephant foot yam papad, to assess the nutritional composition, physical characteristics and organoleptic evaluation of elephant foot yam papad. The papads were made with five different levels of elephant foot yam flour as 10, 20, 30, 40 and 50\% along with control samples. The protein content in papad ranged from 16.20 to $22.50 \mathrm{~g}$, carbohydrate 55.60 to $58.96 \mathrm{~g}$, fat 4.21 to $4.50 \mathrm{~g}$, fibre 3.22 to $3.53 \mathrm{~g}$, calcium 140 to $158 \mathrm{mg} / 100 \mathrm{~g}$, iron 5.50 to $6.29 \mathrm{mg} / 100 \mathrm{~g}$. The overall acceptability score of control sample and supplemented with $30 \%$ elephant foot yam flour was highest (8.50 like extremely). The thickness $(\mathrm{cm})$ and diameter $(\mathrm{cm})$ of papad of control sample was highest and respective values were $0.60 \mathrm{~cm}$ and $14.95 \mathrm{~cm}$ (after frying). The thickness $(\mathrm{cm})$ and diameter $(\mathrm{cm})$ of papad supplemented with $30 \%$ (T3) and $10 \%$ (T1) were least i.e., $0.56 \mathrm{~cm}$ and $13.72 \mathrm{~cm}$ respectively. The expansion (\%) of papad supplemented with 30\% (T3) elephant foot yam flour was highest i.e.16.50\% and least for treatment T1 (10\% supplemented with elephant foot yam flour).
\end{abstract}

\section{Introduction}

Elephant foot yam (Amorphophallus paeoniifolius) is a tropical tuber crop belongs to family Areceae. The important Amorphophallus species i.e. Amorphophallus Peaoniifolius is basically a crop of south East Asian origin. In India, it is commonly known as "Suran" or "Jimikand". Elephant foot yam is a good source of energy, sugar, starch, proteins, fiber as well as minerals (Singh and Wadhwa, 2012). It is majorly used as a vegetable in various Indian, Chinese and Japanese cuisines. It is not only used as vegetable but different value added products like pickles, dried cubes, chips, flour, thickening agent etc are also made and they are gaining popularity 
Elephant foot yam a tuberous root crop is grown as a cash crop due to its high production potential, and popularly as a vegetable in many Asian and African countries (Misra et al., 2002). Tubers also serve as tonic, stomachic and appetizer. It has several medicinal properties like gastro protective ability, antioxidative, antidiarrhoeal and anti-inflammatory activity (Singh, 2015).

Papad is a popular snack item consumed after frying or roasting. Traditionally, different types of cereals and legumes flours are blended to prepare papad to suit the regional preferences. It is commonly made with the blackgram flour and it is largest selling papad in the local and national market (Suradkar et al., 2014)

Elephant foot yam is not exploited for industrial uses, are cultivated in small pockets and used only as vegetables. To make them important component in our food security system of this tubers, it is necessary to develop value added products such as flours or starches (Moorthy, 2002) of this tubers to enhance their potential uses within the food industry. The present experimental study was done to standardize and asses the physicchemical characteristics of papad made with the different levels of elephant foot yam flour.

\section{Materials and Methods}

\section{Procurement of materials}

Good quality tubers of elephant foot yam variety Gajendra was collected from ICARCTCRI, Regional centre campus. Other materials required for product development were procured from local market of Bhubaneswar.

\section{Standardization of papad}

Papad was standardized using elephant foot yam flour at different incorporations of $10,20,30,40$ and 50 percent respectively. The details of processing are given in Table 1.

Table.1 Standardization of Jimikand papad

\begin{tabular}{|l|l|l|l|l|l|l|l|}
\hline $\begin{array}{l}\text { Supplementation } \\
\text { level (\%) }\end{array}$ & $\begin{array}{l}\text { Black } \\
\text { gram } \\
\text { flour } \\
(\mathbf{B G F}) \\
(\mathbf{g})\end{array}$ & $\begin{array}{l}\text { Elephant } \\
\text { Foot } \\
\text { yam } \\
\text { flour } \\
\text { (EFYF) } \\
(\mathbf{g})\end{array}$ & $\begin{array}{l}\text { Common } \\
\text { Salt } \\
\text { (g) }\end{array}$ & $\begin{array}{l}\text { Water } \\
(\mathbf{m l})\end{array}$ & $\begin{array}{l}\text { Papadkhar } \\
(\mathbf{g})\end{array}$ & $\begin{array}{l}\text { Edible } \\
\text { Oil } \\
(\mathbf{g})\end{array}$ & $\begin{array}{l}\text { Asafoetida } \\
\text { (g) }\end{array}$ \\
\hline Control & 100 & --- & 1 & 50 & 4.5 & 7 & 0.5 \\
\hline BGF:EFYF & & & & & & & \\
\hline $\mathbf{9 0 : 1 0}\left(\mathbf{T}_{\mathbf{1}}\right)$ & 90 & 10 & 1 & 50 & 4.5 & 7 & 0.5 \\
\hline $\mathbf{8 0 : 2 0}\left(\mathbf{T}_{\mathbf{2}}\right)$ & 80 & 20 & 1 & 50 & 4.5 & 7 & 0.5 \\
\hline $\mathbf{7 0 : 3 0}\left(\mathbf{T}_{\mathbf{3}}\right)$ & 70 & 30 & 1 & 50 & 4.5 & 7 & 0.5 \\
\hline $\mathbf{6 0 : 4 0}\left(\mathbf{T}_{\mathbf{4}}\right)$ & 60 & 40 & 1 & 50 & 4.5 & 7 & 0.5 \\
\hline $\mathbf{5 0 : 5 0}\left(\mathbf{T}_{\mathbf{5}}\right)$ & 50 & 50 & 1 & 50 & 4.5 & 7 & 0.5 \\
\hline
\end{tabular}

\section{Preparation of elephant foot yam flour}

The tubers were washed in tap water and cut into slices $(1-2 \mathrm{~mm})$. The slices were blanched for $5 \mathrm{~min}$. After blanching, the slices were spread on the trays and were dried in the cabinet drier at $60{ }^{\circ} \mathrm{C}$ for $6 \mathrm{hrs}$. The dried slices were subjected to milling process by 
using pulverizer to obtain the fine flour that was sieved by using the sieve (SSS No.80). The detailed flow chart is mentioned in Figure 1 .

\section{Physico-chemical characteristics of papad}

Thickness of papad, diameter of papad before and after frying, expansion of papad parameters were measured using standard method of AOAC (2000).

\section{Oraganoleptic evaluation of papad}

To ensure the acceptability of the modified recipe used for papad, it was subjected to organoleptic evaluation by using hedonic scale on a scale of 1 to 9 . The scale range defines dislike extremely to like extremely.

\section{Statistical analysis of the data}

The data were analyzed for percentage, mean and single factor analysis of variance (ANOVA) was applied to find the appropriate significant difference among the different foods.

Fig.1 Flow chart

Mixing (All the ingredients)

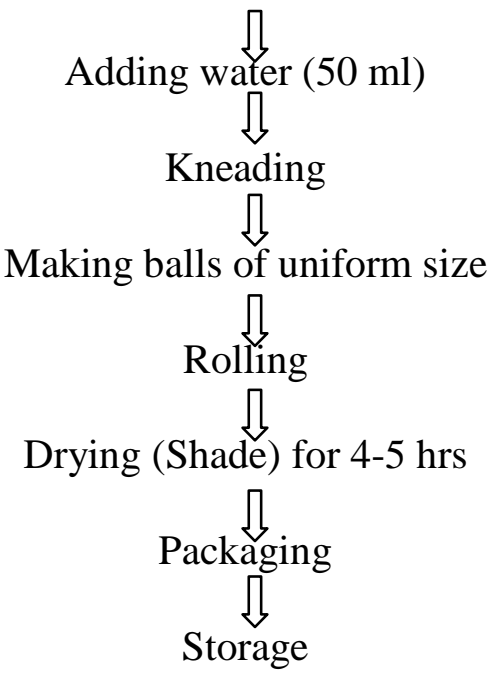

\section{Results and Discussion}

\section{Nutritional composition of papad}

Table 2 shows nutrient content (per 100g) of papad supplemented with elephant foot yam flour with respect to moisture, protein, carbohydrate, fat, fibre, calcium and iron content. The moisture content $(\mathrm{g})$ of papad made with 5 different treatments ranges from 6.50 to 6.59 . There is slight increase in the moisture content of papad with addition of elephant foot yam flour. This might be due to increased absorption of water with addition of elephant foot yam flour during dough preparation. Protein content $(\mathrm{g})$ in the papad ranges from 16.20 to 19.21 . It was found that the protein content increased considerably with addition of elephant foot yam flour. The papad with 50\% of elephant foot yam flour reported highest protein content (19.21g). The increased protein content increased the overall nutritional importance of papad. The Carbohydrate content was found to be 
increasing from $T_{1}$ to $T_{5}$. The carbohydrate content was highest 58.96g in $\mathrm{T}_{5}$ and lowest in control sample. The fat content (g) of papad ranges from 4.21 to 4.50 . It was observed that the fat content of papad decreasing from $T_{1}$ to $T_{5}$. The fat content was highest $(4.50 \mathrm{~g})$ in control sample and lowest in $(4.20 \mathrm{~g})$ in treatment $\mathrm{T}_{5}$. This might be due to low oil absorption capacity of elephant foot yam flour.

Fibre plays the vital role in nutritional composition of food. The fibre content $(\mathrm{g})$ in the papad ranges from 3.22 to 3.53.The fibre content was found to be increasing from $\mathrm{T}_{1}$ to $\mathrm{T}_{5}$. The highest fibre content is $3.53 \mathrm{~g}$ in $\mathrm{T}_{5}$ treatment and lowest fibre content $(3.22 \mathrm{~g})$ in control sample. The calcium and iron content ranges from $140 \mathrm{mg}$ to $158 \mathrm{mg} / 100 \mathrm{~g}$ and 5.50 $\mathrm{mg}$ to $6.29 \mathrm{mg} / 100 \mathrm{~g}$ respectively. It was observed that calcium and iron content increasing from $T_{1}$ to $T_{5}$. This increased calcium and iron content is might be due to increased level of elephant foot yam flour.

Table.2 Nutritional content of healthy papad supplemented with Jimikand flour (JMF) per 100g

\begin{tabular}{|l|l|l|l|l|l|l|l|}
\hline $\begin{array}{l}\text { Supplementations } \\
\text { Level of (\%) of } \\
\text { JMF }\end{array}$ & Moisture & $\begin{array}{l}\text { Protein } \\
\text { (g) }\end{array}$ & $\begin{array}{l}\text { Carbohydrate } \\
\text { (g) }\end{array}$ & Fat $(\mathbf{g})$ & $\begin{array}{l}\text { Fibre } \\
\text { (g) }\end{array}$ & $\begin{array}{l}\text { Calcium } \\
(\mathbf{m g})\end{array}$ & Iron(mg) \\
\hline Control & 6.56 & 22.50 & 55.60 & 4.50 & 3.22 & 140 & 5.50 \\
\hline $\mathbf{T}_{\mathbf{1}}$ & 6.50 & 16.20 & 56.62 & 4.26 & 3.48 & 143 & 5.59 \\
\hline $\mathbf{T}_{\mathbf{2}}$ & 6.53 & 17.41 & 57.27 & 4.24 & 3.50 & 146 & 5.91 \\
\hline $\mathbf{T}_{\mathbf{3}}$ & 6.54 & 18.36 & 57.88 & 4.22 & 3.51 & 153 & 6.20 \\
\hline $\mathbf{T}_{\mathbf{4}}$ & 6.59 & 18.92 & 58.24 & 4.21 & 3.52 & 155 & 6.27 \\
\hline $\mathbf{T}_{\mathbf{5}}$ & 6.58 & 19.21 & 58.96 & 4.21 & 3.53 & 158 & 6.29 \\
\hline C.D & $\mathrm{NS}$ & 0.946 & 0.957 & 0.097 & 0.118 & 9.023 & 0.098 \\
\hline S.E(m) & 0.076 & 0.304 & 0.307 & 0.031 & 0.038 & 2.896 & 0.032 \\
\hline S.E(d) & 0.108 & 0.429 & 0.434 & 0.044 & 0.054 & 4.096 & 0.045 \\
\hline C.V & 2.019 & 2.803 & 0.926 & 1.267 & 1.895 & 3.363 & 0.916 \\
\hline
\end{tabular}

Table.3 Oraganoleptic evaluation of papad supplemented with Elephant Foot Yam Flour (EFYF) per $100 \mathrm{~g}$

\begin{tabular}{|l|l|l|l|l|l|}
\hline $\begin{array}{l}\text { Supplementations } \\
\text { Level of }(\%) \text { of } \\
\text { JMF }\end{array}$ & Colour & Texture & Flavour & Taste & $\begin{array}{l}\text { Overall } \\
\text { Acceptability }\end{array}$ \\
\hline Control & 8.50 & 8.40 & 8.50 & 8.50 & 8.50 \\
\hline $\mathbf{T}_{\mathbf{1}}$ & 8.50 & 8.30 & 8.30 & 8.20 & 8.20 \\
\hline $\mathbf{T}_{\mathbf{2}}$ & 8.50 & 8.30 & 8.20 & 8.10 & 8.20 \\
\hline $\mathbf{T}_{\mathbf{3}}$ & 8.50 & 8.40 & 8.30 & 8.40 & 8.40 \\
\hline $\mathbf{T}_{\mathbf{4}}$ & 8.00 & 8.10 & 8.00 & 8.00 & 8.00 \\
\hline $\mathbf{T}_{\mathbf{5}}$ & 7.90 & 7.90 & 7.80 & 7.70 & 7.80 \\
\hline C.D & 0.208 & $\mathrm{NS}$ & 0.328 & 0.36 & 0.344 \\
\hline S.E(m) & 0.067 & 0.129 & 0.105 & 0.115 & 0.111 \\
\hline S.E(d) & 0.094 & 0.183 & 0.149 & 0.163 & 0.156 \\
\hline C.V & 1.388 & 2.716 & 2.231 & 2.454 & 2.340 \\
\hline
\end{tabular}


Table.4 Physical characteristics of healthy papad supplemented with Elephant foot yam flour (EFYF) per 100gm

\begin{tabular}{|l|l|l|l|l|}
\hline $\begin{array}{l}\text { Supplementations } \\
\text { Level of }(\%) \text { of } \\
\text { JMF }\end{array}$ & $\begin{array}{l}\text { Thickness of } \\
\text { papad }(\mathbf{c m})\end{array}$ & \multicolumn{2}{|l|}{ Diameter of papad (cm) } & Expansion (\%) \\
\hline & & Before frying & After frying & \\
\hline Control & 0.60 & 12.91 & 14.95 & 15.80 \\
\hline $\mathbf{T}_{\mathbf{1}}$ & 0.58 & 12.20 & 13.72 & 12.45 \\
\hline $\mathbf{T}_{\mathbf{2}}$ & 0.58 & 12.20 & 13.75 & 12.70 \\
\hline $\mathbf{T}_{\mathbf{3}}$ & 0.56 & 12.00 & 13.98 & 16.50 \\
\hline $\mathbf{T}_{\mathbf{4}}$ & 0.57 & 12.20 & 13.95 & 14.34 \\
\hline $\mathbf{T}_{\mathbf{5}}$ & 0.57 & 12.50 & 14.20 & 13.60 \\
\hline C.D & NS & 0.160 & 0.222 & 0.184 \\
\hline S.E(m) & 0.011 & 0.051 & 0.071 & 0.059 \\
\hline S.E(d) & 0.016 & 0.073 & 0.101 & 0.083 \\
\hline C.V & 3.395 & 0.721 & 0.877 & 0.717 \\
\hline
\end{tabular}

The similar results are found in biscuits supplemented with amorphophallus paeoniifolius flour (Yadav Anjali and Singh Sadhana, 2018).

\section{Oraganoleptic evaluation of papad}

Data illustrated in Table 4 shows the oragnoleptic evaluation of papad. Colour score of control sample and sample supplemented with 10,20,30\% elephant foot yam flour were highest and same i.e. 8.50 (like extremely). Texture score of control sample and 30\% elephant foot yam flour was highest i.e.8.40 (like extremely). Flavour score of control sample and $30 \%$ supplements of papad was highest compared with other samples. Overall acceptability of control sample and $30 \%\left(\mathrm{~T}_{3}\right)$ supplemented elephant foot yam flour was highest.

\section{Physical characteristics of papad}

Table 3 shows the effect of supplementation of elephant foot yam flour on the papad making characteristics with respect to it thickness $(\mathrm{cm})$, Diameter $(\mathrm{cm})$ and Expansion $(\%)$. The thicknesses of five samples were ranging from $0.560 \mathrm{~cm}\left(\mathrm{~T}_{5}\right)$ to $0.60 \mathrm{~cm}$ (control). The thickness of papad slightly decreased with addition of elephant foot yam flour.

The diametrical expansion of five samples ranges from 12.45 to $16.50 \%$. The highest expansion of $\mathrm{T}_{3}(30 \%)$ addition of EFY flour and lowest of $\mathrm{T}_{1}(10 \%)$ of EFY flour. The expansion (\%) of papad was increased from treatments $T_{1}$ to $T_{3}$ but from treatments $T_{4}$ to $\mathrm{T}_{6}$ expansion was slightly decreased. These results are good agreement with sorghum papad had highest expansion (\%) 22.2\% (Chavan et al., 2015).

\section{References}

A.O.A.C. 2000. Official Methods of Analysis $17^{\text {th }}$ Edn. Association of Official Analytical Chemist. Washington, DC.

Chavan,U.D., Pansare, S.S., Patil, J.V and Shinde, M.S (2015) Preparation and nutritional quality of sorghum papad. Int.J.Curr.Microbiol.App.Sci， 4(5): 806-823.

Misra, R.S, Nedunchezhiyan, M and Swamy, T.M.S (2002) Amorphophallus 
paeoniifolius: A high value cash crop for coastal areas. In national conference on coastal Agriculture Research, ICAR Research Complex, Goa, April 6-7.

Moorthy, S. N (2002). Physicochemical and functional properties of tropical tuber starches: a review. Starch-Stärke. vol. 54 (12) pp. 559-592, 2002.

Singh A (2015). Phytoconstitutent characteristics and application of Amorphophallus paeoniifolius in development of food products, Ph.D Thesis, Jaypee Institute of Information Technology, Noida, India.

Singh A and Wadhawa N (2012).Osmotic dehydration of Elephant foot yam slices and its phytochemicals investigation. International journal of pharmacy and life sciences, 3(7):17971801.

Suradkar, N.G., Pawar, D.A and Kamble, D.G (2014) Studies on Standardization and shelf life determination of soya fortified urad papad. International journal of Science, engineering and Technology, Vol. 3(11): 2935-2940.

Yadav Anjali and Singh Sadhna (2018) Effect of supplementation of Amorphophallus paeoniifolius flour on sweet Biscuits making characteristics, Int.J.Curr.Microbiol.App.Sci, 7:336342.

\section{How to cite this article:}

Venkatraman Bansode, Vijay Bahadur Singh Chauhan, Kalidas pati, Kiran Bhuyar Sudhansu Shekhar Mahanand and Nedunchezhiyan, M. 2019. Studies on Standardization and Physicchemical Characteristics of Elephant Foot Yam (Amorphophallus paeoniifolius) Papad. Int.J.Curr.Microbiol.App.Sci. 8(05): 950-955. doi: https://doi.org/10.20546/ijcmas.2019.805.110 